JURNAL TEKNOLOGI

AGRO-INDUSTRI

Vol. 2 No. 2 ; November 2015

\title{
OPTIMASI PRODUKSI BIOBRIKET DARI KULIT BUAH KARET
}

\author{
RACHMAT RAMADHANI, DWI SANDRI, JAKA DARMA JAYA
}

Jurusan Teknologi Industri Pertanian, Politeknik Negeri Tanah Laut

Jl. A. Yani, Km.6, Ds. Panggung, kec. Pelaihari, kab. Tanah Laut, Kalimantan Selatan

Naskah diterima : 6 Agustus 2015; Naskah disetujui : 10 September 2015

\begin{abstract}
ABSTRAK
Biobriket merupakan energi alternatif pengganti bahan bakar yang dihasilkan dari bahan-bahan organik atau biomasa yang kurang termanfaatkan. Beberapa jenis limbah biomasa memiliki potensi yang cukup besar seperti limbah kayu, sekam padi, jerami, ampas tebu, cangkang sawit. Penelitian ini bertujuan untuk mengoptimasi produksi biobriket dari kulit buah karet dengan parameter pengujian meliputi analisis kadar air, nilai kalor, lama bakar dan laju bakar. Pembuatan biobriket ini berbahan baku dari kulit buah karet yang dimulai dari proses pengarangan kemudian digiling dan dicampur dengan perekat dan cetak lalu dijemur. Adapun perekat yang digunakan adalah tepung tapioka dengan konsentrasi perekat 3\%, 4\%, 5\%, dan 6\% pada pembuatan biobriket dan air yang digunakan sebanyak $250 \mathrm{ml}$ dan $375 \mathrm{ml}$ terhadap masing-masing konsentrasi. Hasil penelitian menunjukan bahwa briket dengan perlakuan menggunakan perekat 4\% yang dilarutkan dengan $250 \mathrm{ml}$ air mendekati SNI briket arang. Hasil tersebut menunjukan kadar air 6,12\%, nilai kalor 6351,58 kal/gr, lama bakar 43 menit dan laju bakarnya 0,28 gr/menit. Melihat dari hasil penelitian ini bahwa kulit buah karet dapat dijadikan salah satu bahan baku alternatif dalam pembuatan biobriket.
\end{abstract}

Kata kunci : Kulit buah karet, Tapioka, Biobriket

\section{PENDAHULUAN}

Kehidupan manusia modern membutuhkan energi dalam jumlah yang besar, hampir tidak ada satu sisipun dari kehidupan manusia modern yang lepas dari kebutuhan energi. Sejak ditemukan batubara, minyak bumi, dan gas alam, sumber utama pemenuhan kebutuhan energi bersandar pada sumber-sumber tersebut. Bahan bakar alternatif yang populer saat ini adalah bioenergi, yaitu energi yang bersumber dari sumberdaya yang dapat diperbaharui. Sumberdaya tersebut meliputi matahari, air, angin, panas bumi dan energi yang didapat dari biomasa.

Pemanfaatan limbah pertanian sebagai salah satu sumber energi alternatif yang diharapkan juga dapat menggeser atau mensubtitusi pemakaian kayu bakar untuk rumah tangga. Kayu sebagai bahan bakar dinegara sedang berkembang mencapai 75 sampai 90 persen secara keseluruhan (Agussalim 1995 dalam Usman 2007).

Limbah pertanian yang merupakan biomasa tersebut merupakan sumber energi alternatif yang melimpah dengan kandungan energi yang relatif besar. Limbah pertanian tersebut dapat diolah menjadi suatu bahan bakar padat buatan yang lebih luas penggunaannya sebagai bahan bakar alternatif yang disebut biobriket.

Salah satu limbah pertanian tersebut adalah kulit buah karet. Kulit buah karet merupakan bagian kulit terluar dari buah karet yang memiliki karateristik keras dan menyerupai seperti kayu serta selama ini 
hanya dianggap sebagai sampah pertanian. Oleh karena itu kulit buah karet ini dapat dimanfaatkan sebagai pembuatan biobriket dan dapat meningkatkan nilai ekonomisnya.

*Korespondensi :

Telepon : 082552619311

Email : dhanirachmat27@gmail.com

\section{VELITIAN}

Alat yang digunakan pada penelitian ini adalah neraca analitik, plastik, baskom, labu erlenmeyer,sendok, panci, kompor gas, ayakan dan lesung. Sedangkan bahan yang digunakan adalah kulit buah karet, tepung tapioka dan air. Kulit buah karet yang digunakan dikumpulkan dari lahan perkebunan karet masyarakat Desa Batu Mulya Kecamatan Panyipatan, Pelaihari Kalimantan Selatan.

\section{Proses Pengarangan}

Kulit buah karet yang telah dikumpulkan kemudian akan dibuat arang dengan cara dibakar. Pembuatan arang dari kulit buah karet ini dilakukan didalam tanah dengan terlebih dahulu dibuat lubang. Kulit buah karet yang sudah dibakar pada mulut lubang tanah ditutup dengan pelepah batang pisang dan karung basah. Tujuannya adalah agar kulit buah karet yang telah dibakar agar menjadi arang, proses ini juga sekaligus sebagai proses pendinginan. Arang kulit buah karet yang sudah terbentuk kemudian dihaluskan dan diayak dengan ukuran 36 mesh.

\section{Proses Pembuatan Biobriket}

Kulit buah karet yang telah diolah menjadi bubuk arang terlebih dahulu ditimbang sebanyak 250 gr. Adapun tahapan dalam pembuatan biobriket dari kulit buah karet ini adalah sebagai berikut :

1. Pelarut $250 \mathrm{ml}$ air

Tepung tapioka ditimbang 3\% terhadap sampel. Kemudian dilarutkan dengan air sebanyak 250 $\mathrm{ml}$ dan dimasak beberapa menit sampai agak mengental. Setelah itu dicampurkan dengan sampel dan dibuat adonan sampai homogen antara perekat dengan sampel. Untuk pembuatan perekat dengan konsentrasi 4\%, 5\%, dan 6\% dilakukan dengan cara yang sama seperti sebelumnya.

2. Pelarut $375 \mathrm{ml}$ air

Pembuatan perekat dengan konsentrasi 3\%, 4\%, 5\%, dan 6\% dilakukan dengan cara yang sama seperti sebelumnya, namun hanya kadar pelarutnya saja yang berbeda yakni sebanyak $375 \mathrm{ml}$.

Konsentrasi pembuatan biobriket dari kulit buah karet dapat dilihat pada gambar 1.

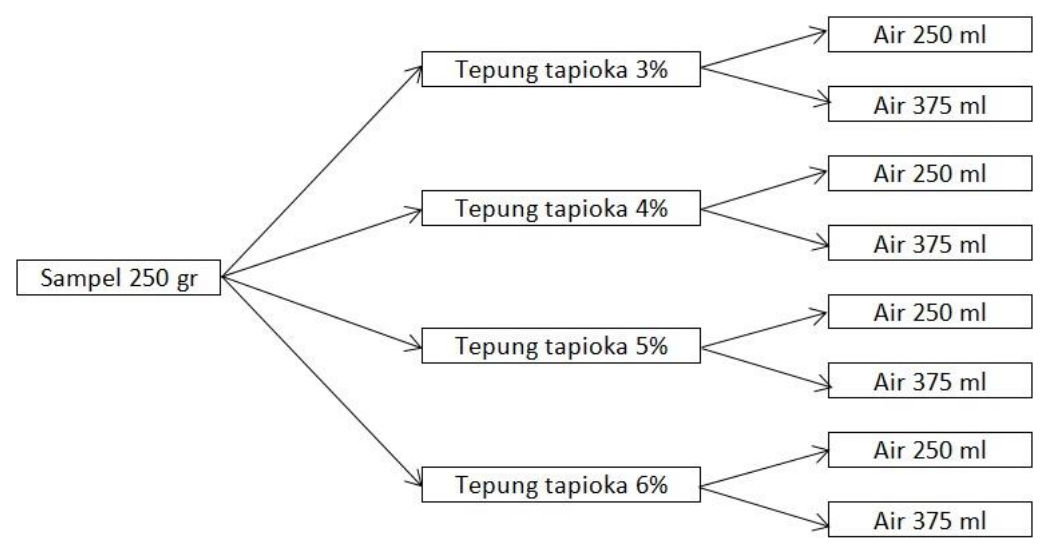

Gambar 1. Skema Formulasi Pembuatan Biobriket 
Pemberian larutan tepung tapioka bertujuan sebagai perekat dari biobriket kulit buah karet yang akan diolah. Adonan yang telah siap kemudian akan dicetak dengan cetakan berbentuk silinder dengan diameter $5 \mathrm{~cm}$ dan tinggi $2 \mathrm{~cm}$. Biobriket yang telah dicetak kemudian diberi kode dengan nama A3, A4, A5, A6, B3, B4, B5 dan B6. Adapun dengan keterangan dari kode tersebut adalah sebagai berikut :

A3 : Larutan 3\% tepung tapioka terhadap sampel dengan pelarut $250 \mathrm{ml}$ air

A4 : Larutan $4 \%$ tepung tapioka terhadap sampel dengan pelarut $250 \mathrm{ml}$ air

A5 : Larutan 5\% tepung tapioka terhadap sampel dengan pelarut $250 \mathrm{ml}$ air

A6 : Larutan 6\% tepung tapioka terhadap sampel dengan pelarut $250 \mathrm{ml}$ air

B3 : Larutan 3\% tepung tapioka terhadap sampel dengan pelarut $375 \mathrm{ml}$ air

B4 : Larutan $4 \%$ tepung tapioka terhadap sampel dengan pelarut $375 \mathrm{ml}$ air

B5 : Larutan 5\% tepung tapioka terhadap sampel dengan pelarut $375 \mathrm{ml}$ air

B6 : Larutan 6\% tepung tapioka terhadap sampel dengan pelarut $375 \mathrm{ml}$ air

Biobriket kulit buah karet yang sudah dicetak kemudian memasuki tahap selanjutnya yakni tahap pengeringan. Pengeringan dilakukan dengan cara dijemur pada terik matahari selama 3 hari.

\section{Pengujian Biobriket}

Biobriket yang telah siap akan dianalisis kualitasnya dan akan dibandingkan dengan Standar kualitas biobriket menurut SNI. Pengujian briket kulit buah karet ini meliputi uji kadar air, uji nilai kalor, uji lama bakar dan uji laju bakar.

\section{HASIL DAN PEMBAHASAN}

Untuk menganalisa kualitas biobriket yang dihasilkan maka diperlukan beberapa pengujian, hasil dari pengujian tersebut kemudian disajikan dalam bentuk tabel. Hasil rata-rata pengujian ini dapat dilihat pada tabel 1 .

Tabel 1. Hasil Pengujian Biobriket

\begin{tabular}{|c|c|c|c|c|c|}
\hline Perlakuan & $\begin{array}{c}\text { Kadar } \\
\text { Air (\%) }\end{array}$ & $\begin{array}{c}\text { Nilai kalor } \\
\text { (kal/gram) }\end{array}$ & $\begin{array}{c}\text { Berat Briket } \\
\text { yang dibakar } \\
\text { (gram) }\end{array}$ & $\begin{array}{c}\text { Lama } \\
\text { Bakar } \\
\text { (menit) }\end{array}$ & $\begin{array}{c}\text { Laju Bakar } \\
\text { (gram/menit) }\end{array}$ \\
\hline $\begin{array}{c}\text { (SNI } \\
\text { No.1/6235/2000) }\end{array}$ & $\leq 8,00$ & $\geq 5000$ & - & - & - \\
\hline A3 & 6,20 & 6096,04 & 11,41 & 40 & 0,29 \\
\hline A4 & 6,12 & 6351,58 & 12,06 & 43 & 0,28 \\
\hline A5 & 7,03 & 5942,39 & 13,29 & 46 & 0,29 \\
\hline A6 & 7,12 & 6169,50 & 12,52 & 45 & 0,28 \\
\hline B3 & 6,26 & 6122,68 & 11,91 & 42 & 0,28 \\
\hline B4 & 6,34 & 6065,57 & 11,93 & 42 & 0,28 \\
\hline B5 & 7,36 & 6086,13 & 13,62 & 47 & 0,29 \\
\hline B6 & 7,41 & 6064,48 & 13,66 & 46 & 0,30 \\
\hline
\end{tabular}

Rata - rata hasil uji untuk kadar air biobriket dari kulit buah karet ini dengan perlakuan dan konsentrasi berbeda antara A3, A4, A5, dan A6 yakni kadar air terendah sebesar 6,12\% diperoleh dari perlakukan A4. Bila dibandingkan dengan standar briket arang menurut SNI yaitu $\leq 8 \%$, maka biobriket 
dari kulit buah karet dalam penelitian ini memenuhi syarat mutu tersebut. Kadar air briket diharapkan serendah mungkin agar nilai kalornya tinggi dan mudah dinyalakan. Kadar air mempengaruhi kualitas briket yang dihasilkan. Pada tabel dapat terlihat bahwa semakin besar kadar perekat maka semakin besar pula kadar airnya. Hal ini sesuai dengan penelitian Sumangat dan Broto (2009) yang menunjukkan bahwa semakin tinggi konsentrasi perekat kadar airnya semakin besar, baik pada briket arang, briket kayu dan briket limbah arang aktif. Kadar air briket ditentukan oleh banyak faktor. Menurut Sumangat dan Broto (2009), kemampuan menyerap air pada briket dipengaruhi oleh luas permukaan dan pori-pori bahan. Usman (2007) menambahkan bahwa briket yang berasal dari bahan baku yang berkerapatan rendah memiliki kadar air yang lebih tinggi daripada briket dengan bahan baku berkerapatan tinggi.

Nilai kalor biobriket dari kulit buah karet ini bervariasi yakni mulai dari 5942,39 kal/gram sampai $6351,58 \mathrm{kal} / \mathrm{gram}$. Melihat dari tabel nilai kalor yang terbesar yakni terdapat pada perlakukan A4 yakni sebesar 6351,58 kal/gram. Nilai kalor biobriket dari kulit buah karet ini bila dibandingkan dengan standar mutu briket arang menurt SNI maka keseluruhan perlakuan memenuhi mutu standar yang ditetapkan yakni minimal $5000 \mathrm{kal} / \mathrm{gram}$. Nilai kalor juga dipengaruhi oleh ukuran partikel arang. Pada penelitian ini ukuran partikel arang yang dibuat briket hanya satu ukuran saja yakni 36 mesh, maka cenderung nilai kalor yang dihasilkan selisihnya tidak terlalu signifikan. Hal ini sejalan dengan Usman (2007), mengatakan bahwa kayu dengan berat jenis tinggi cenderung menghasilkan briket dengan nilai kalor tinggi. Nilai kalor briket sangatlah penting karena ada kaitannya dengan efefsiensi atau penghematan suatau bahan bakar. Apabila nilai kalor rendah berati jumlah bahan bakar yang digunakan dan diibutuhkan untuk pembakaran atau pemanasan akan lebih banyak, tetapi bila nilai kalornya tinggi berati jumlah bahan bakar yang digunakan untuk pembakaran akan lebih sedikit, nilai kalor biobriket ini menjadi parameter dalam menentukan kualitasnya. Semakin tinggi nilai kalor suatu biobriket maka semakin tinggi pula kualitas dan harga jualnya.

Lama bakar Biobriket dari kulit buah karet ini bervariasi yakni mulai dari 40 menit sampai 46 menit. Melihat dari tabel 1, lama bakar yang diperoleh dari berbagai macam perlakuan diperoleh bahwa dengan kode perlakuan A5 yang terlama sedangkan yang tercepat yaitu dengan kode perlakuan A3. Menurut Jamilatun (2008) kecepatan pembakaran dipengaruhi oleh struktur bahan, kandungan karbon terikat dan tingkat kekerasan bahan, secara teoritis jika kandungan senyawa volatilnya tinggi maka briket akan mudah terbakar dengan kecepatan pembakaran tinggi.

Laju bakar biobriket dari kulit buah karet ini bervariasi yakni mulai dari 0,28 gr/menit sampai 0,29 gr/menit. Tabel 1. menunjukan laju bakar dengan perlakuan A4 memiliki nilai paling kecil yaitu 0,28 gr/menit. Semakin kecil nilai laju bakar maka semakin baik kualitas biobriketnya. Hal ini dikarenakan dalam waktu yang sama, massa biobriket yang kecil. Sundari dan Sari (2012) menyatakan bahwa salah satu faktor yang mempengaruhi proses pembakaran bahan bakar padat adalah ukuran partikel bahan bakar 
padat yang kecil, dengan partikel yang lebih kecil ukurannya, maka suatu bahan bakar padat akan lebih cepat terbakar.

\section{KESIMPULAN}

Perlakuan A4 merupakan perlakuan yang terbaik, dimana kadar air 6,12\%, nilai kalor 6351,58 $\mathrm{kal} / \mathrm{gr}$, lama bakar 40 menit, dan laju bakarnya 0,28 gr/menit. Jadi melihat dari hasil penelitian ini bahwa kulit buah karet dapat dijadikan sebagai salah satu bahan baku alternatif dalam pembuatan biobriket.

\section{UCAPAN TERIMAKASIH}

Terima kasih disampikan kepada Politeknik Negeri Tanah Laut atas bantuan fasilitas, materil dan non materil dalam pelaksanaaan penelitian ini.

\section{DAFTAR PUSTAKA}

American Society for Testing and Materials. 2001.Standard Test Method for Chemical Analysis of Wood Charcoal. ASTM International. Philadephia, USA.

Enie, A.B, 1989 , Teknologi Pengolahan Singkong, Balai Besar Litbang Industri Hasil Pertanian Bogor, Departemen Perindustrian.

Jamilatun, S. 2008. Sifat-Sifat Penyalaan dan Pembakaran Briket Biomassa, Briket Batubara dan Arang Kayu. Jurnal Rekayasa Proses 2(2): 37 - 40.

Pamungkas, P.S., I. W. Joniarta, M. Wijana. 2014. Pengaruh Besaran Butiran Biji Jaraj dan Arang Sekam Padi pada Briket dengan perekat kanji dan Tanah Liat terhadap kadar Air, Nilai Kalor, dan Laju Pembakaran. Jurnal Energi dan Manufaktur. Vol 7 No 2: 119-224.

Santosa. Misliani dan Anugrah, S. P. 2010. Studi Variasi Komposisi Bahan Penyusun Briket Dari Kotoran Sapi dan Limbah Pertanian. Laporan Penelitian. Jurusan Teknik Pertanian. Fakulas Teknologi Pertanian. Universitas Andalas Kampus Limau Manis. Padang.

Silalahi, 2000. Penelitian pembuatan Briket Kayu dari serbuk Gergajian Kayu. Bogor: Hasil Penelitian Industri Deperindag.

Sumangat, D. dan Broto, W. 2009. Kajian teknis dan ekonomis pengolahan briket bungkil biji jarak pagar sebagai bahan bakar tungku. Buletin Teknologi Pascapanen. 5 : 18 - 26.

Sundari, E. dan Sari, E. 2012. Pembuatan Biobriket Dari Limbah Cangkang Kakao. Jurnal Litbang Industri. 2(1): $32-38$.

Usman, M. N. 2007. Mutu Briket Arang Kulit Buah Kakao Dengan Menggunakan Kanji Sebagai Perekat. Jurnal Perennial. 3(2) : $55-58$. 